\title{
Proteomic characterisation of drug metabolising enzymes and drug transporters in pig liver
}

DOI:

10.1080/00498254.2020.1763513

\section{Document Version}

Accepted author manuscript

Link to publication record in Manchester Research Explorer

\section{Citation for published version (APA):}

Elmorsi, Y., Al Feteisi, H., Al-Majdoub, Z., Barber, J., Rostami-Hodjegan, A., \& Achour, B. (2020). Proteomic characterisation of drug metabolising enzymes and drug transporters in pig liver. Xenobiotica. https://doi.org/10.1080/00498254.2020.1763513

\section{Published in:}

Xenobiotica

\section{Citing this paper}

Please note that where the full-text provided on Manchester Research Explorer is the Author Accepted Manuscript or Proof version this may differ from the final Published version. If citing, it is advised that you check and use the publisher's definitive version.

\section{General rights}

Copyright and moral rights for the publications made accessible in the Research Explorer are retained by the authors and/or other copyright owners and it is a condition of accessing publications that users recognise and abide by the legal requirements associated with these rights.

\section{Takedown policy}

If you believe that this document breaches copyright please refer to the University of Manchester's Takedown Procedures [http://man.ac.uk/04Y6Bo] or contact uml.scholarlycommunications@manchester.ac.uk providing relevant details, so we can investigate your claim.

\section{OPEN ACCESS}


Xenobiotica

the fate of foreign compounds in biological systems

\title{
Proteomic Characterisation of Drug Metabolising Enzymes and Drug Transporters in Pig Liver
}

\author{
Yasmine Elmorsi, Hajar Al Feteisi, Zubida M. Al-Majdoub, Jill Barber, Amin \\ Rostami-Hodjegan \& Brahim Achour
}

To cite this article: Yasmine Elmorsi, Hajar Al Feteisi, Zubida M. Al-Majdoub, Jill Barber, Amin Rostami-Hodjegan \& Brahim Achour (2020): Proteomic Characterisation of Drug Metabolising Enzymes and Drug Transporters in Pig Liver, Xenobiotica, DOI: 10.1080/00498254.2020.1763513

To link to this article: https://doi.org/10.1080/00498254.2020.1763513

田货

Accepted author version posted online: 30 Apr 2020.

Submit your article to this journal 지

凹 Article views: 45

Q View related articles ๘

View Crossmark data 


\section{Proteomic Characterisation of Drug Metabolising Enzymes and Drug Transporters in Pig Liver}

Yasmine Elmorsi ${ }^{\mathrm{a}}$, Hajar Al Feteisi ${ }^{\mathrm{a}}$, Zubida M. Al-Majdoub ${ }^{\mathrm{a}}$, Jill Barber ${ }^{\mathrm{a}}$, Amin RostamiHodjegan $^{\mathrm{a}, \mathrm{b}}$ and Brahim Achour ${ }^{\mathrm{a}^{*}}$

${ }^{a}$ Centre for Applied Pharmacokinetic Research, University of Manchester, Stopford Building, Oxford Road, Manchester, M13 9PT, UK; ${ }^{\mathrm{b}}$ Certara UK Ltd. (Simcyp Division), 1 Concourse Way, Sheffield, S1 2BJ, UK

Correspondence to: Brahim Achour, Centre for Applied Pharmacokinetic Research, University of Manchester, Stopford Building, Oxford Road, M13 9PT, email: brahim.achour@manchester.ac.uk 


\section{Abstract}

1. Liver enzymes and transporters play an essential role in xenobiotic metabolism, distribution and elimination. Pre-clinical safety assessment relies on studies on animal models, including the (mini)pig. The pig shares many anatomical and physiological characteristics with humans, and there is currently a gap in information about porcine metabolism and disposition pathways and their similarities and differences from human ones.

2. Three different sample preparation methods (filter-aided sample preparation (FASP), enhanced FASP (eFASP) and in-solution sample preparation) were used to prepare porcine liver tissue (two samples) for proteomic analysis. The analysis relied on rapidseparation liquid chromatography coupled to Orbitrap mass spectrometry in datadependent acquisition mode. MASCOT was used for identification and relative label-free quantification was based on spectral counting.

3. The three sample preparation methods provided complementary results, allowing characterisation of approximately 70 pharmacologically relevant proteins. The main quantified proteins included 16 cytochrome P450 (CYP) enzymes, 5 UGT enzymes, and 11 transporters. In addition, 20 Phase I and 14 Phase II enzymes were also characterised. Inter-operator differences were negligible and the pig liver pies for CYP, UGT and efflux transporter proteins were established. Human homologues of the quantified CYP, UGT and transporter proteins were identified.

Keywords: Enzymes, Transporters, Proteomics, Pig, Quantification 


\section{Introduction}

Hepatic enzymes and transporters play a key role in xenobiotic biotransformation, distribution and elimination, and therefore these proteins govern drug safety and efficacy (Heikkinen et al., 2015). Pre-clinical safety assessment has traditionally relied on animal models, such as rats, beagle dogs and cynomolgus monkeys. Fuelled by efforts by the RETHINK consortium, the (mini)pig has recently started to be more widely used as a model for toxicology and translational medical research (Forster et al., 2010; Suenderhauf \& Parrott, 2013). This is mainly because these animals share many characteristics with humans, especially in anatomy, physiology, and biochemistry (Forster et al., 2010; Helke \& Swindle, 2013).

In addition, the pig has a significant agricultural value, accounting for about $38 \%$ of consumed meat products. Therefore, drugs used to improve animal health and meat production (e.g., antibiotics), along with other xenobiotics and their metabolites, are easily transferred onto human metabolism through the food cycle (Chang et al., 2015). These xenobiotics are metabolised and eliminated by metabolic and disposition pathways, mediated by drug-metabolising enzymes and drug transporters. Recently, the domestic pig genome was successfully sequenced (Groenen et al., 2012), and studies have demonstrated extensive homology between human and pig cytochrome P450 (CYP) sequences ranging between $60 \%$ and 95\% (Achour et al., 2011). Despite this level of interest in the pig, there is little information about other porcine metabolism and disposition pathways.

LC-MS proteomics has increasingly been applied to generate reliable quantitative information about enzymes and transporters in various systems (Al Feteisi et al., 2015). Advantages of proteomics include sensitivity, selectivity, reproducibility, wide dynamic range and ability to quantify various targets in the same experiment (Couto et al., 2019). Label-free proteomic quantification offers a low cost approach to protein characterisation 
with reasonably high reliability (Ishihama et al., 2005). Quality of the generated data however tends to be dependent on availability of high quality samples and on the suitability of sample preparation methodology (Prasad et al., 2019).

We have previously attempted to characterise pig liver cytochrome P450 enzymes using label-free proteomic methodology and reported relative abundance levels (Achour et al., 2011). To build on this study, the present work aimed to identify and relatively quantify pig liver proteins involved in drug metabolism and disposition. The identification and quantification of porcine analogues of human proteins involved in drug metabolism and disposition is intended to shed light on pharmacological pathways that can best be studied using the pig as a model. For this assessment, three different sample preparation techniques were used to provide complementary data about pig liver proteomic profiles, and quantitative characterisation focused on Phase I and Phase II enzymes and transporters.

\section{Material and Methods}

\section{Chemicals and Reagents}

All chemicals and materials were purchased from Sigma-Aldrich (Poole, Dorset, UK) unless otherwise specified. Lysyl endopeptidase (Lys-C) was purchased from Wako (Osaka, Japan) and proteomic-grade trypsin was supplied by Roche Applied Science (Mannheim, Germany). Solvents were supplied by Thermo Fisher Scientific (Paisley, UK) and were of analytical grade or higher.

\section{Preparation of Porcine Liver Microsomal Fractions}

Two individual pig livers (female, adult, Large White) were sourced from a local butcher (Manchester, UK). Tissue was cleaned and cut into pieces smaller than $1 \mathrm{~cm}^{3}$ and stored at - 
$80^{\circ} \mathrm{C}$ until further use. Tissue samples were defrosted on ice, and $1 \mathrm{~g}$ of tissue from each sample was minced and processed by homogenisation using a mechanical tissue homogeniser in $10 \mathrm{ml}$ homogenisation buffer (10 mM HEPES, pH 7.4, 1 mM EDTA, $1 \mathrm{mM}$ dithiothreitol, $0.2 \mathrm{mM}$ Pefabloc and $0.15 \mathrm{mM} \mathrm{KCl}$ ) as previously described (Langenfeld et al., 2009). Microsomal fractions were prepared by differential centrifugation (Beckman Coulter, Inc., Fullerton, CA) at $10000 \mathrm{~g}$ for $20 \mathrm{~min}$, followed by centrifugation at $100000 \mathrm{~g}$ for $75 \mathrm{~min}$. The microsomal pellet was then resuspended in phosphate buffer $(0.25 \mathrm{M}$ potassium phosphate, $\mathrm{pH} 7.25)$ at $1 \mathrm{ml}$ per gram tissue.

\section{Determination of Microsomal Protein Content and Assessment of Recovery}

Microsomal protein content was measured by bicinchoninic acid (BCA) assay according to the manufacturer's protocol. The activity of NADPH cytochrome P450 reductase was monitored at $550 \mathrm{~nm}$ using a Jenway UV-Vis spectrophotometer (Staffordshire, UK) in kinetic mode, according to the manufacturer's instructions. The protein content was corrected for loss from processing using recovery ratios estimated from the initial linear phase of cytochrome $\mathrm{P} 450$ reductase activity in microsomes relative to homogenates, corresponding to $1 \mathrm{mg}$ of tissue as previously described (Achour et al., 2011).

\section{Sample Preparation of Microsomal Protein for Mass Spectrometry}

Protein $(50 \mu \mathrm{g})$ from each liver microsomal sample (Liver 1 and 2 ) was prepared for LC-MS analysis by two different operators (Operator 1 and 2) using three different sample preparation methods, namely filter-aided sample preparation (FASP), enhanced filter-aided sample preparation (eFASP) and in-solution sample preparation.

$\boldsymbol{F A S P}$. Filter-aided preparation of samples followed the method published by Wiśniewski et al. (2009) with some modifications. Briefly, microsomal proteins were solubilised in $10 \%$ (w/v) sodium deoxycholate in protein LoBind tubes (Eppendorf, Stevenage, UK), followed 
by reduction of protein disulfide bridges in $0.1 \mathrm{M}$ Tris- $\mathrm{HCl}$ buffer, $\mathrm{pH} 8.5$, containing $60 \mathrm{mM}$ dithiothreitol and $8 \mathrm{M}$ urea and incubation with mixing at $56^{\circ} \mathrm{C}$ for $30 \mathrm{~min}$. Ultracel centrifugal filter units (Amicon Ultra, Merck) were washed twice with $200 \mu \mathrm{l}$ of $8 \mathrm{M}$ urea in 0.1 M Tris- $\mathrm{HCl}, \mathrm{pH} 8.5$, followed by centrifugation at $14000 \mathrm{~g}$ for $20 \mathrm{~min}$ for each wash step. Samples were then added to filter units and centrifuged at $14000 \mathrm{~g}$ for $30 \mathrm{~min}$, followed by alkylation with $50 \mathrm{mM}$ iodacetamide in $8 \mathrm{M}$ urea and $0.1 \mathrm{M}$ Tris- $\mathrm{HCl}, \mathrm{pH} 8.5$, in the dark at room temperature for $20 \mathrm{~min}$. Buffer exchange to $1 \mathrm{M}$ urea in $50 \mathrm{mM}$ ammonium bicarbonate buffer, $\mathrm{pH}$ 8.0, was performed. Sequential digestion with Lys-C ( $\left.2 \% \mathrm{w} / \mathrm{w}, 4 \mathrm{~h}, 30^{\circ} \mathrm{C}\right)$, followed by trypsin $\left(5 \%\right.$ w/w, $\left.16 \mathrm{~h}, 37^{\circ} \mathrm{C}\right)$ was carried out before collection of peptides by centrifugation into fresh collection microcentrifuge tubes. The use of Lys-C before trypsin serves to reduce miscleavages and increase the depth of proteomic analysis (Achour \& Barber, 2013; Wiśniewski, 2016).

$\boldsymbol{e F A S P}$. The same procedure as FASP was followed with some modifications; filter units and collection tubes were passivated overnight in $5 \%(\mathrm{v} / \mathrm{v})$ Tween ${ }^{\circledR} 20$ on a shaker before being rinsed, and washed twice in MS-grade water for $30 \mathrm{~min} .50 \mu \mathrm{g}$ of microsomal protein was mixed with $1 \mathrm{M}$ dithiothreitol in $100 \mathrm{mM}$ ammonium bicarbonate and incubated at $56^{\circ} \mathrm{C}$ for $40 \mathrm{~min}$. The protein solution was mixed with $8 \mathrm{M}$ urea and $0.2 \%$ deoxycholic acid in 100 $\mathrm{mM}$ ammonium bicarbonate, $\mathrm{pH} 8.0$, and transferred to the passivated filter units and centrifuged at $14000 \mathrm{~g}$ for $10 \mathrm{~min}$. Successive solubilisation and alkylation were performed using $0.2 \%$ deoxycholic acid and $50 \mathrm{mM}$ iodoacetamide, respectively, before filters were transferred to passivated collection tubes for sequential digestion by Lys-C and trypsin as described for FASP. Deoxycholic acid was removed at the end of the protocol by phase transfer using ethyl acetate and trifluroacetic acid as a white, visible precipitate. Tubes were then filled with ethyl acetate, sonicated and centrifuged and the upper organic layer was discarded. After repeating the previous step 3-5 times, tubes were incubated for $5 \mathrm{~min}$ in a 
thermo-mixer at $60^{\circ} \mathrm{C}$ to remove ethyl acetate before the samples were concentrated in a vacuum centrifuge (Erde et al., 2014).

In-solution digestion. Microsomal protein was solubilised with sodium deoxycholate, and samples were reduced, alkylated, and digested as previously described (Harwood et al., 2015). Detergent was removed by precipitation with trifluoroacetic acid $(0.1 \% \mathrm{v} / \mathrm{v})$ before collection of peptides by centrifugation (14000 rpm at $4^{\circ} \mathrm{C}$ for $\left.15 \mathrm{~min}\right)$.

\section{Samples Desalting and Purification}

For the FASP and in-solution preparation methods, desalting of samples was performed using C18 ZipTips (Millipore, Watford, UK), according to the manufacturer's protocol. For eFASP, this step was unnecessary because of the phase transfer step performed at the end of the protocol as described above.

\section{LC-MS/MS Analysis of Prepared Liver Samples}

LC-MS data acquisition. Digested microsomal samples were analysed by LC-MS/MS on an UltiMate ${ }^{\circledR} 3000$ Rapid Separation LC (RSLC, Dionex Corporation, Sunnyvale, CA) coupled to an Orbitrap Elite (Thermo Fisher Scientific, Waltham, MA) mass spectrometer. Peptides were separated using a multistep gradient from $95 \%$ Buffer A (0.1\% formic acid (FA) in water) and $5 \%$ Buffer $\mathrm{B}(0.1 \% \mathrm{FA}$ in acetonitrile) to $7 \% \mathrm{~B}$ at $1 \mathrm{~min}, 22 \% \mathrm{~B}$ at $58 \mathrm{~min}, 30 \% \mathrm{~B}$

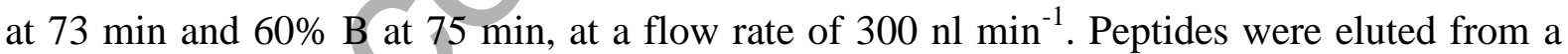
CSH C18 analytical column (75 $\mathrm{mm}$ x $250 \mu \mathrm{m}$ i.d., $1.7 \mu \mathrm{m}$ particle size) (Waters, UK). MS/MS data were collected in data-dependent mode to automatically select the 10 most abundant peptides in each scan for fragmentation by collision-induced dissociation.

Proteomic data analysis and protein quantification. Data were searched using Mascot (Matrix Science Ltd., London, UK) using the following criteria; databases: Swissprot + TrEMBL, enzyme: trypsin/P, taxonomy: Sus scrofa, fixed modifications: carbamidomethyl 
(C), variable modification: oxidation $(\mathrm{M})+$ deamidation $(\mathrm{N}, \mathrm{Q})$, peptide charge states: $2+$ and $3+$, and allowing up to 2 missed cleavages. Relative abundance was estimated for the proteins of interest (Phase I and II drug-metabolising enzymes and drug transporters) using label-free quantification based on the exponentially modified protein abundance index (emPAI) (Ishihama et al., 2005). The observed peptides from each protein were identified for each sample and duplicates were removed. Wherever there was more than one accession code for any protein, the presence of isoforms for such protein was investigated. The relative abundance of enzymes and transporters was calculated using the Equations (1) and (2).

$$
\begin{aligned}
& \text { PAI }=\frac{\text { Number of observed peptides }}{\text { Number of observable peptides }} \\
& \text { emPAI }=10^{\text {PAI }}-1
\end{aligned}
$$

For cytochrome P450 (CYP), uridine 5'-diphospho-glucuronosyltransferase (UGT) and ATPbinding cassette $(\mathrm{ABC})$ transporters, the percentage relative abundance was calculated based on Equation (3).

$$
\text { Protein abundance }(\%)=\left(\text { emPAI }_{\text {Protein }_{i}} / \sum_{\mathrm{i}=1}^{\mathrm{n}} \operatorname{emPAI}_{\text {Protein }_{\mathrm{i}}}\right) \times 100
$$

Where the percent molar abundance of protein $i$ is measured relative to the total abundance of $n$ proteins quantified in each family (CYP, UGT enzymes and ABC transporters). The number of observable peptides was generated using in silico digests of protein sequences using MS-Digest tool on ProteinProspector version 2.6.1 (University of California, San Francisco, CA).

\section{Sequence Homology between Porcine and Human Enzymes and Transporters}

A search was performed for each pig protein sequence against UniProt and NCBInr databases using its accession code, and FASTA files were obtained. The presence of unique peptides was confirmed by searching identified peptide sequences using basic local alignment search 
tool (BLAST) against UniProtKB database for mammals. Human homologues of the identified pig proteins were determined using the EMBOSS (European Molecular Biology Open Software Suite) Needleman-Wunsch pairwise alignment algorithm (Needleman \& Wunsch, 1970) by iterative alignment. Sequences were matched against human isoform sequences for enzymes and transporters within the same families of the porcine proteins. Matching homologues were identified based on percentage identity and similarity as previously described (Achour et al., 2011).

\section{Results}

\section{Microsomal Protein Content of Porcine Liver (MPPGL)}

The microsomal fraction was isolated from two pig livers using differential centrifugation of tissue homogenates. Microsomal protein content was measured for the two samples using a BCA assay. Protein loss during processing was estimated using NADPH cytochrome P450 reductase activity (microsomal membrane marker), where homogenates and microsomal fractions from the same tissue samples were assayed. Recovery of microsomal protein was calculated using the ratio of the linear initial rate of reaction (Achour et al., 2011). The recovery of microsomal protein ranged from $46.3 \%$ to $49.3 \%$, and enrichment of microsomal fractions was 2.0-3.6 fold for the two liver samples. The recovery was used to estimate loss in microsomal protein and microsomal protein per gram liver (MPPGL), which is used as a scaling factor in in vitro-in vivo extrapolation (IVIVE), was estimated. The mean MPPGL for the two samples was $29.1 \mathrm{mg}$ protein per gram of porcine liver tissue (individual values, 34.6 and $23.6 \mathrm{mg} \mathrm{g}^{-1}$ liver tissue in Liver 1 and 2, respectively). 


\section{Global Reproducibility of Pig Liver Proteomic Analysis}

Microsomal fractions isolated from the two pig liver samples were prepared by three distinct sample preparation protocols to compare the range of proteins that can be identified using each of the three methods (filter-aided sample preparation (FASP), enhanced FASP (eFASP) and in-solution sample preparation). Each sample preparation method was performed by two operators. Data generated for each liver by each protocol and by each operator are supplied in Supplementary Information. A summary of the numbers of proteins and peptides identified by each method and each operator is provided in Table S1.

The number of identified proteins was similar between FASP and solution-based protocols (approximately 1250 proteins on average), and this was consistently lower with eFASP (approximately 950 proteins). The data showed high reproducibility by all methods (10-16\% variability in identified proteins) and comparable performance by the two operators (12\% and $18 \%$ variability). This led to limited technical variability $(<20 \%$ variability in identified proteins) in the analysis of both livers.

\section{Complementarity of Identified Enzymes and Transporters between Sample Preparation}

\section{Methods}

Data generated by the three different protocols were analysed and pig liver drug-metabolising enzymes and drug transporters were identified and relatively quantified. The ranges of pharmacologically relevant proteins quantified using the three methods and their overlap are shown in Figure 1. Quantified cytochrome P450, UGT and transporter proteins are listed in Table 1.

$<$ Table 1>

$<$ Figure 1> 
Qualitative data presented in this study represent a combination of the results from the two pig livers processed by the three sample preparation methods and by the two operators. Some of the identified drug-metabolising enzymes and drug transporters could be isolated from the samples prepared only by one or two of the sample preparation protocols. For example, in the case of ABCG2 (BCRP), razor/unique peptides related to this transporter could be detected using the FASP protocol, while no peptides were observed when the other two methods were followed (Table S2). On the other hand, CYP2C42 and ABCC1 (MRP1) peptides were found only in samples processed by eFASP. Similarly, some proteins were identified only when FASP and in-solution preparation methods were used, including CYP3A29 and CYP3A46. Proteins quantified by one or two of these methods are presented in the Venn diagram in Figure 1B. There were very little inter-operator differences.

\section{Identification and Annotation of Porcine Liver Enzymes and Transporters}

Proteomic analysis by LC-MS/MS allowed identification of approximately 150 database entries as drug-metabolising enzymes and transporters in total. After removal of duplicated entries and truncated proteins, this number decreased to approximately 70 . The list of proteins also included the basolateral membrane marker $\left(\mathrm{Na}^{+} / \mathrm{K}^{+}\right.$ATPase $)$and cytochrome P450 auxiliary proteins (NADPH cytochrome P450 reductase and cytochrome b5). In total, 16 cytochrome P450 enzymes, 5 UGT enzymes, and 11 transporters could be identified (Table 2). In addition to CYP and UGT enzymes, the numbers of identified drugmetabolising enzymes were 20 and 14 for Phase I and Phase II, respectively (Table 3).

Several of the identified proteins were not completely annotated by available repositories, and were shown in database searches as uncharacterised proteins. For these proteins, unique peptides were searched using a basic local alignment search tool (BLAST) against the UniProtKB database to determine the most probable candidate pig proteins, and subsequently these were putatively identified using iterative Needleman-Wunsch pairwise alignment with 
the corresponding mammalian enzyme and transporter subfamily sequences. Three of the identified UGT enzymes (UGT1A1, UGT1A3 and UGT2B17) and two transporters (ABCA8 and $\mathrm{ABCC} 1$ ) could be assigned using this approach. For UGT2B31, no suggested entry could be found in UniProtKB, and therefore the NCBInr database was searched instead and the protein was assigned as the listed isoform (Table 2).

\section{Relative Quantification of Porcine Liver Enzymes and Transporters using Spectral}

\section{Counting}

The exponentially modified protein abundance index (emPAI) was calculated for each protein and used as a relative quantification measure. Values are reported in Table 2A, B and C for CYPs, UGTs and transporters, respectively, and in Table 3 for additional Phase I and Phase II drug-metabolising enzymes. Out of the quantified proteins, 12 CYP enzymes were considered as drug-metabolising proteins, belonging to families 1-3 (CYP pie chart in Figure 2A). The CYP families of highest abundance were CYP2A (14\%), CYP2C (32\%), CYP2D (22\%), CYP2E (10\%), and CYP3A (17\%). The most abundant individual CYP enzymes were CYP2D25, CYP2A19 and CYP2C49 with relative abundance of 22\%, $14 \%$ and $11.5 \%$, respectively. Similar pie charts for the quantified UGT enzymes and ABC transporters are shown in Figure $2 \mathrm{~B}$ and $\mathrm{C}$, respectively. Relative quantification of Phase I and phase II drugmetabolising enzymes was carried out using the same methodology, and their relative expression values are presented in Figure 3. Variability between the levels of CYPs, UGTs and transporters in the two pig livers was lower than $25 \%$ (Table 2).

$<$ Table 2>

$\langle$ Table 3>

$<$ Figure 2> 
$<$ Figure 3>

\section{Identification of Human Homologues of Porcine Enzymes and Transporters}

The human homologues of each of the identified porcine proteins could be assigned using the EMBOSS pairwise alignment tool provided by the European Bioinformatics Institute (EBI). Human homologues with the highest identity and similarity are listed in Table 4. Many of the porcine CYP enzymes were equivalent to human homologues sharing the same nomenclature; namely, CYP1A2, CYP2E1, CYP2S1, CYP4V2, CYP20A1 and CYP51A1. In addition, CYP2A19 and CYP2D25 were shown to be highly similar (>75\% identity, >85\% similarity) to human CYP2A6/13 and CYP2D6, respectively, whereas CYP2C33 was similar to human CYP2C9 (>60\% identity, >75\% similarity). CYP2C34, CYP2C42 and CYP2C49 were highly similar to human CYP2C18. All identified porcine CYP3A subfamily showed high homology to the same human subfamily. Similarly, porcine CYP4A21 was the equivalent of human CYP4A11. Several of the identified UGT enzymes and some transporters were putatively identified. For this, only few sequences could be compared to their human homologues. The sequence of UGT1A6 was shown to be conserved between pig and human. Similarly, all identified porcine transporters that had a UniProtKB annotation were equivalent to their human homologues except porcine OATP1B4 which was shown to be highly similar to human OATP1B3.

The relative abundance of pig liver enzymes and transporters were compared to their identified human homologues (Table 4). The human data were collated from recently published meta-analyses for CYPs (Achour et al., 2014a), UGTs (Achour et al., 2014b) and transporters (Burt et al., 2016). Differences between pig and human expression profiles were most apparent in the absence of various enzymes and transporters in pig liver, including CYP2B6, CYP2J2, CYP4F and OATP1B1. Another contrast is that the homologues of the most abundant CYP enzymes in pig liver [CYP2A19 (14\%) and CYP2D25 (22\%)] are 
expressed at low abundance in human liver [CYP2A6 (7\%) and CYP2D6 (3\%)]. The most abundant CYP family of enzymes in human liver, CYP3A (32\%), was of considerably lower abundance in pig liver (17\%). CYP2C represents the main similarity in abundance between pig and human (32\% and 25\%, respectively). Likewise, UGT2B (48\% and 54\%, respectively) and hepatic efflux transporters, MRPs (29\% and 35\%, respectively) and P-gp (5\% and 3\%, respectively), showed very similar trends of relative expression in pig and human liver.

$<$ Table 4>

\section{Discussion}

Pigs have received considerable attention not only because to their agricultural importance as a food source, but also owing to their value in research. Conventional pigs and minipigs are widely used as laboratory animals for biomedical and pharmaceutical research, mainly because they are physiologically similar to humans (Colleton et al., 2016; Lunney, 2007). Although there is evidence that pigs have a comparable metabolic system (Lunney, 2007), little is known about the genomic and proteomic similarities and differences between pigs and humans, and how these translate into similarities or difference in drug metabolism and disposition. In this study, we adopted a qualitative and quantitative approach to investigate the protein expression of Phase I and II drug-metabolising enzymes and drug transporters in pig liver.

The MPPGL of the two pig livers was estimated to be approximately $29.1 \mathrm{mg}$ per gram liver tissue (range: 23.6-34.6 $\mathrm{mg} \mathrm{g}^{-1}$ liver tissue ), which confirms the results obtained by Achour et al. (2011), who reported a mean of $34.4 \mathrm{mg} \mathrm{g}^{-1}$. This value is comparable to the mean human MPPGL of $32 \mathrm{mg} \mathrm{g}^{-1}$ reported previously (Barter et al., 2007). However, our results seem to be somewhat lower than the reported values, possibly due to protein loss in centrifugation steps (Harwood et al., 2014). 
In proteomics, a variety of sample preparation and quantitative methods have been developed to identify and quantify proteins, and each has its advantages and limitations (Al Feteisi et al., 2015). The strategy adopted in this study used three different sample preparation methods (FASP, eFASP and in-solution) to compare the ability of each to extract liver proteins. Two consecutive steps were followed, identification and relative quantification. The number of identified enzymes and transporters by each of the three methods was comparable for each protein set; 14 CYP and 5 UGT enzymes were identified by each of the three methods, while the number of identified transporters was 10 with FASP and eFASP, and 8 with in-solution sample preparation. This does not necessarily imply that the three methods were always able to isolate the same proteins. In spite of the extensive overlap, different methods tended to identify specific proteins consistently. For example, CYP2C42 and ABCC1 (MRP1) could only be identified when eFASP was used, while CYP3A29 and CYP3A46 were successfully isolated by the two other methods. ABCG2 (BCRP) was consistently isolated by FASP, and the uptake transporter SLCO1B4 (OATP1B4) was not observed with the solution-based protocol. We therefore propose a new definition of replication, for practical purposes, where the same sample is prepared using different protocols, which provide complementary results, and this can then be used to construct a more comprehensive qualitative and quantitative description of the expression patterns of pharmacologically relevant proteins.

The identification step indicated the expression of 7 drug-metabolising CYP subfamilies, CYP1A, CYP2A, CYP2C, CYP2D, CYP2E, CYP2S, and CYP3A, comprising 12 isoforms. Quantitatively, CYP2C was the most abundant subfamily (at 32\% of hepatic CYP content) followed by CYP2D (22\%), CYP3A (17\%), CYP2A (14\%) and CYP2E (10\%). This finding is in line with previously reported pig liver pie (Achour et al., 2011), where CYP2A, CYP2D, CYP2C and CYP3A were the most abundance subfamilies. This trend is also in agreement with more recent proteomic studies on the pig and minipig (Millecam et al., 2018; Rasmussen 
et al., 2019). The most abundant individual CYP enzymes were also the same as previously reported; CYP2D25 (22\%), CYP2A19 (14\%) and CYP2C49 (11.5\%). Compared to the previous pig liver CYP pie (Achour et al., 2011), more isoforms could be identified and quantified; namely, CYP2C34, CYP2C42, CYP2S1, CYP3A22, and CYP3A46; however, CYP3A39 was not quantified in this study.

To identify human homologues, analysis of CYP sequence homology was carried out. Our results agreed with the sequence homology analysis of CYP enzymes reported by Achour et al. (2011). The findings showed 72-95\% identity and 80-98\% similarity for all porcine CYP enzymes, with the exception of CYP2C 33 , which showed low identity of $63 \%$ with high similarity of $80 \%$ to human CYP2C9. CYP2C49 was highly similar to both human CYP2C18 and CYP2C8. Porcine CYP2D25 was homologous to human CYP2D6. Previously detected CYP3A29 and 3A46 had similarity and identity up to $88 \%$ and $77 \%$ to human CYP3A4/5. This was also the case with porcine CYP3A22. Newly identified CYP2C34 and 2C42 showed high similarity and identity to human CYP2C18. CYP1A2 and CYP2E1 are conserved in pig and human, in line with previous research (Gonzalez, 2002). This was also the case for CYP2S1, CYP4V2, CYP20A1, and CYP51A1. High sequence homology between human and pig isoforms suggest similar substrate specificity, as previously reported (Anzenbacher et al., 1998).

Upon comparison of our findings with the human liver cytochrome P450 pie (Michaels \& Wang, 2014, Achour et al., 2014a), some differences could be identified. First, CYP3A is the most abundant human CYP subfamily followed by CYP2C and CYP2E, which is not the case in the pig. Moreover, one of the most significant inter-species differences is the case of the highly abundant porcine CYP2D25 (22\%), which is the pig counterpart of the low abundance human CYP2D6, expressed in human liver at 3\% of total drug-metabolising CYP content. 
Other human subfamilies include CYP2B, CYP2J and CYP4F, which were not identified in pig liver. These discrepancies can be attributed to inter-species differences and some variability may be due to the different techniques used in quantification in the two sets, where human data were generated using targeted quantitative proteomics, either by QconCAT (Achour et al., 2014c) or stable isotope-labeled peptides (Michaels \& Wang, 2014). The pig proteomic data remain to be confirmed by targeted analysis, which will enable better comparison of human and porcine expression profiles using absolute abundance levels.

Uridine 5'-diphospho-glucuronosyltransferases (UGTs) are the most important Phase II drugmetabolising enzymes responsible for xenobiotic glucuronidation; these enzymes have high sequence homology and overlapping substrate specificities (Guillemette et al., 2014). Because they are membrane-bound enzymes with their sequences located on the luminal side of the membrane, their isolation can be challenging. Only five porcine UGT enzymes could be identified in these experiments, four of which (UGT1A1, UGT1A3, UGT2B17, and UGT2B31) were identified as uncharacterised proteins in the UniProtKB database. We putatively identified these isoforms using iterative Needleman-Wunsch pairwise alignment against the corresponding human UGT enzyme sequences. For these putatively identified proteins, sequence homology with human counterparts reached $70-81 \%$ identity and $83-90 \%$ similarity, while the database-annotated UGT1A6 had identity and similarity of $80 \%$ and $87 \%$, respectively. The main similarity between the expression levels of pig and human UGT enzymes was the dominant contribution of UGT2B subfamily (at $48 \%$ and $54 \%$, respectively). The results obtained for UGTs should be considered preliminary and may need to be revisited when better annotated and more comprehensive databases are available.

To date, proteomic analysis conducted in pig has only focused on drug-metabolising enzymes, with no previous reports investigating porcine drug transporters; this may be due to 
the difficulty in isolating these membrane-embedded proteins and lack of established proteomic methods targeted at pig transporters. In this study, 11 transporters were identified, out of which 9 were of the $\mathrm{ABC}$ family. Relative quantification of $\mathrm{ABC}$ transporters was as follows: $\mathrm{ABCA} 8(8 \%), \mathrm{ABCB} 1(5 \%), \mathrm{ABCB} 11$ (15\%), $\mathrm{ABCC} 1(2 \%), \mathrm{ABCC} 2(13 \%)$, ABCC3 (14\%), ABCF1 (7\%), ABCE1 (31\%) and ABCG2 (5\%). ABCA8 and ABCC1 were putatively identified by sequence alignment. Other transporters identified included uptake transporters SLCO1B4 and SLCO2B1; however, the main human SLCO transporter, SLCO1B1, was not identified in pig liver. Similarity in expression levels between pig and human was observed mainly for efflux MRP (ABCC) and P-gp (ABCB1) transporters.

In conclusion, this study employed complementary sample preparation methods in conjunction with label-free proteomics to identify and quantify a large number of enzymes and transporters in pig liver. The putative identification undertaken in this study highlights the need for further annotation of existing mammalian databases. Abundance data, such as those reported in this study, can serve to populate translational quantitative systems pharmacology models used to predict drug pharmacology and toxicity in patients (Suenderhauf \& Parrott, 2013). Limitations of the current study include the low sample size (2 livers) and the level of quantification achieved (relative quantification).

\section{Acknowledgements}

The authors thank the Biological Mass Spectrometry BioMS for access to mass spectrometry instruments, the Egyptian Government for sponsoring Yasmine Elmorsi and CAPKR consortium (Janssen, Certara, Merck, MSD, Genentech, Takeda Pharmaceuticals and Eli Lilly) for support. 


\section{Disclosure statement}

The authors report no declarations of interest.

\section{References}

Achour B, Barber J, Rostami-Hodjegan A. (2011). Cytochrome P450 pig liver pie: Determination of individual cytochrome P450 isoform contents in microsomes from two pig livers using liquid chromatography in conjunction with mass spectrometry. Drug Metab Dispos 39:2130-34.

Achour B, Barber J. (2013). The activities of Achromobacter lysyl endopeptidase and Lysobacter lysyl endoproteinase as digestive enzymes for quantitative proteomics. Rapid Commun Mass Spectrom 27:1669-72.

Achour B, Barber J, Rostami-Hodjegan A. (2014a). Expression of hepatic drug-metabolizing cytochrome p450 enzymes and their intercorrelations: a meta-analysis. Drug Metab Dispos 42:1349-56.

Achour B, Rostami-Hodjegan A, Barber J. (2014b). Protein expression of various hepatic uridine 5'-diphosphate glucuronosyltransferase (UGT) enzymes and their intercorrelations: a meta- analysis. Biopharm Drug Dispos 35:353-61.

Achour B, Russell MR, Barber J, Rostami-Hodjegan A. (2014c). Simultaneous quantification of the abundance of several cytochrome P450 and uridine 5'-diphosphoglucuronosyltransferase enzymes in human liver microsomes using multiplexed targeted proteomics. Drug Metab Dispos 42:500-10.

Al Feteisi H, Achour B, Rostami-Hodjegan A, Barber J. (2015). Translational value of liquid chromatography coupled with tandem mass spectrometry-based quantitative proteomics 
for in vitro - in vivo extrapolation of drug metabolism and transport and considerations in selecting appropriate techniques. Expert Opin Drug Metab Toxicol 11:1357-69.

Anzenbacher P, Anzenbacherová E, Gut I, et al. (1998). Presence and activity of cytochrome P450 isoforms in minipig liver microsomes; Comparison with human liver samples. Drug Metab Dispos 26:56-9.

Barter Z, Bayliss MK, Beaune PH, et al. (2007). Scaling factors for the extrapolation of in vivo metabolic drug clearance from in vitro data: Reaching a consensus on values of human microsomal protein and hepatocellularity per gram of liver. Curr Drug Metab 8 (1), $33-45$.

Chang Q, Wang W, Regev-Yochay G, et al. (2015). Antibiotics in agriculture and the risk to human health: How worried should we be? Evol Appl 8:240-47.

Colleton C, Brewster D, Chester A, et al. (2016). The use of minipigs for preclinical safety assessment by the pharmaceutical industry. Toxicol Pathol 44:458-66.

Couto N, Al-Majdoub ZM, Achour B, et al. (2019). Quantification of proteins involved in drug metabolism and disposition in the human liver using label-free global proteomics. Mol Pharm 16:632-47.

Erde J, Loo RRO, Loo JA. (2014). Enhanced FASP (eFASP) to increase proteome coverage and sample recovery for quantitative proteomic experiments. J Proteome Res, 13:1885-95.

Forster R Bode G, Ellegaard L, van der Laan JW. (2010). The RETHINK project on minipigs in the toxicity testing of new medicines and chemicals: Conclusions and recommendations. J Pharmacol Toxicol Methods 62:236-42.

Gonzalez FJ. (2002). Transgenic models in xenobiotic metabolism and toxicology. Toxicology 181-182:237-39.

Groenen MAM, Archibald AL, Uenishi H, et al. (2012). Analyses of pig genomes provide insight into porcine demography and evolution. Nature 491:393-98. 
Guillemette C, Levesque E, Rouleau M. (2014). Pharmacogenomics of human uridine diphospho-glucuronosyltransferases and clinical implications. Clin Pharmacol Ther 96:324-39.

Harwood MD, Russell MR, Neuhoff S, et al. (2014). Lost in centrifugation! Accounting for transporter protein losses in quantitative targeted absolute proteomics. Drug Metab Dispos 42:1766-72.

Harwood MD, Achour B, Russell MR, et al. (2015). Application of an LC-MS/MS method for the simultaneous quantification of human intestinal transporter proteins absolute abundance using a QconCAT technique. Journal Pharm Biomed Anal 110:27-33.

Heikkinen AT, Lignet F, Cutler P, Parrott N. (2015). The role of quantitative ADME proteomics to support construction of physiologically based pharmacokinetic models for use in small molecule drug development. Proteomics Clin Appl, 9:732-44.

Helke KL, Swindle MM. (2013). Animal models of toxicology testing: the role of pigs. Expert Opin Drug Metab Toxicol 9:127-39.

Burt HJ, Riedmaier AE, Harwood MD, et al. (2016). Abundance of hepatic transporters in Caucasians: a meta-analysis. Drug Metab Dispos 44:1550-61.

Ishihama Y, Oda Y, Tabata T. (2005). Exponentially modified protein abundance index (emPAI) for estimation of absolute protein amount in proteomics by the number of sequenced peptides per protein. Mol Cell Proteomics 4:1265-72.

Langenfeld E, Zanger UM, Jung K, et al. (2009). Mass spectrometry-based absolute quantification of microsomal cytochrome P450 2D6 in human liver. Proteomics, 9:231323.

Lunney JK. (2007). Advances in swine biomedical model genomics. Int J Biol Sci 3:179-84. 
Michaels S, Wang MZ. (2014). The revised human liver cytochrome P450 "pie": Absolute protein quantification of $\mathrm{CYP} 4 \mathrm{~F}$ and $\mathrm{CYP} 3 \mathrm{~A}$ enzymes using targeted quantitative proteomics. Drug Metab Dispos 42:1241-51.

Millecam J, De Clerck L, Govaert E, et al. (2018). The ontogeny of cytochrome P450 enzyme activity and protein abundance in conventional pigs in support of preclinical pediatric drug research. Front Pharmacol 9:470.

Needleman SB, Wunsch CD. (1970). A general method applicable to search for similarities in amino acid sequence of two proteins. J Mol Biol 48:443-53.

Prasad B, Achour B, Artursson P, et al. (2019). Toward a consensus on applying quantitative liquid chromatography- tandem mass spectrometry proteomics in translational pharmacology research: A white paper. Clin Pharmacol Ther 106:525-43.

Rasmussen MK, Scavenius C, Gerbal-Chaloin S, Enghild J. (2019). Sex dictates the constitutive expression of hepatic cytochrome $\mathrm{P} 450$ isoforms in Gottingen minipigs. Toxicol Lett 314:181-86.

Suenderhauf C, Parrott N. (2013). A physiologically based pharmacokinetic model of the minipig: Data compilation and model implementation. Pharm Res 30:1-15.

Wiśniewski JR, Zougman A, Nagaraj N, Mann M. (2009). Universal sample preparation method for proteome analysis, Nat Methods 6:359-62.

Wiśniewski JR (2016). Quantitative evaluation of filter aided sample preparation (FASP) and multienzyme digestion FASP Protocols. Anal Chem 88:5438-43. 
Table 1 The number (A) and list (B) of identified cytochrome P450, UGT and transporter proteins in pig liver microsomes using three different proteomic sample preparation methods (A)

\begin{tabular}{|c|c|c|c|c|}
\hline & FASP & eFASP & In-solution & Total \\
\hline Cytochrome P450 enzymes & 14 & 14 & 14 & 16 \\
\hline UGT enzymes & 5 & 5 & 5 & 5 \\
\hline Transporters & 10 & 10 & 8 & 11 \\
\hline \multicolumn{5}{|l|}{ (B) } \\
\hline & FASP & eFASP & & In-solution \\
\hline \multirow{16}{*}{ 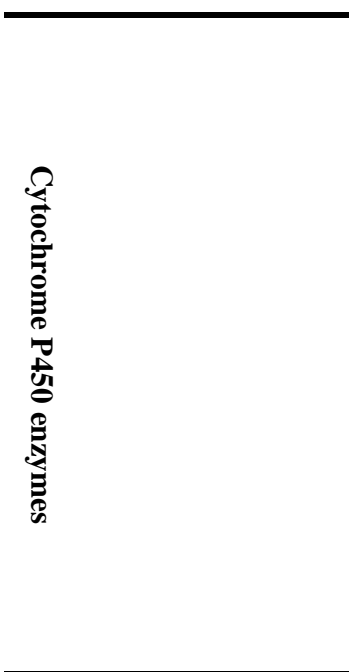 } & CYP1A2 & CYP1A2 & & CYP1A2 \\
\hline & CYP2A19 & CYP2A19 & & CYP2A19 \\
\hline & CYP2C33 & CYP2C33 & & CYP2C33 \\
\hline & CYP2C34 & CYP2C34 & & CYP2C34 \\
\hline & - & CYP2C42 & & - \\
\hline & CYP2C49 & CYP2C49 & & CYP2C49 \\
\hline & CYP2D25 & CYP2D25 & & CYP2D25 \\
\hline & CYP2E1 & CYP2E1 & & CYP2E1 \\
\hline & CYP2S1 & CYP2S1 & & - \\
\hline & CYP3A22 & CYP3A22 & & CYP3A22 \\
\hline & CYP3A29 & - & & CYP3A29 \\
\hline & CYP3A46 & - & & CYP3A46 \\
\hline & CYP4A21 & CYP4A21 & & CYP4A21 \\
\hline & - & CYP4V2 & & CYP4V2 \\
\hline & CYP20A1 & CYP20A1 & & CYP20A1 \\
\hline & CYP51A1 & CYP51A1 & & CYP51A1 \\
\hline \multirow{4}{*}{ 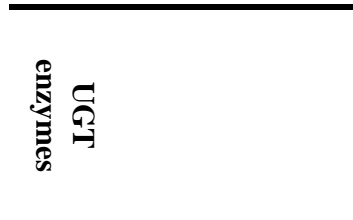 } & UGT1A1* & UGT1A1* & & $\overline{\text { UGT1A1 }}$ \\
\hline & $\begin{array}{l}\text { UGT1A3* } \\
\text { UGT1A6 }\end{array}$ & $\begin{array}{c}\text { UGT1A3* } \\
\text { UGT1A6 }\end{array}$ & & $\begin{array}{c}\text { UGT1A3* } \\
\text { UGT1A6 }\end{array}$ \\
\hline & UGT2B17* & UGT2B $17 *$ & & UGT2B17* \\
\hline & UGT2B $31 *$ & UGT2B31* & & UGT2B $31 *$ \\
\hline \multirow{13}{*}{ 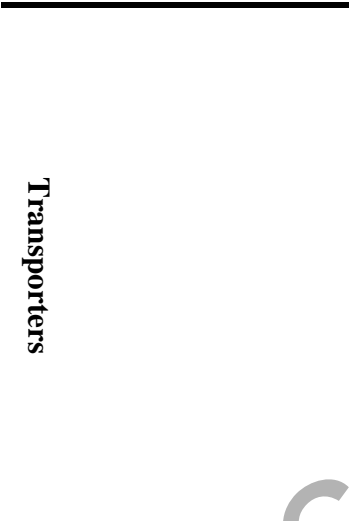 } & ATP1A1 $1^{\S}$ & $\overline{\mathrm{ATP}} 1 \mathrm{~A} 1^{\S}$ & & ATP1A1 ${ }^{\S}$ \\
\hline & $\mathrm{ATP} 1 \mathrm{~B} 1^{\S}$ & ATP1B1 ${ }^{\S}$ & & $\mathrm{ATP} 1 \mathrm{~B} 1^{\S}$ \\
\hline & ABCA8* & АВCA8* & & ABCA8* \\
\hline & $\mathrm{ABCB} 1$ & $\mathrm{ABCB} 1$ & & $\mathrm{ABCB} 1$ \\
\hline & ABCB 11 & $\mathrm{ABCB} 11$ & & $\mathrm{ABCB} 11$ \\
\hline & & $\mathrm{ABCC} 1 *$ & & - \\
\hline & $\mathrm{ABCC} 2$ & $\mathrm{ABCC} 2$ & & $\mathrm{ABCC} 2$ \\
\hline & $\mathrm{ABCC} 3$ & $\mathrm{ABCC} 3$ & & $\mathrm{ABCC} 3$ \\
\hline & $\mathrm{ABCF} 1$ & $\mathrm{ABCF} 1$ & & $\mathrm{ABCF} 1$ \\
\hline & & ABCE1 & & ABCE1 \\
\hline & & - & & - \\
\hline & OATP2B1 & OATP2B1 & & OATP2B1 \\
\hline & OATP1B4 & OATP1B4 & & - \\
\hline
\end{tabular}

* Porcine enzymes and transporters were putatively identified using iterative Needleman-Wunsch pairwise alignment against corresponding mammalian subfamily sequences

$\S$ ATP1A1 and $1 \mathrm{~B} 1$ are $\mathrm{Na}^{+} / \mathrm{K}^{+}$ion transporters and markers for the basolateral membrane of hepatocytes 
Table 2 Cytochrome 450 enzymes (A), UGT enzymes (B), and transporters (C) identified by LCMS/MS and their relative quantification. emPAI is calculated based on combined data from the analysis of two livers. The individual data represent values for each sample considered separately (Liver 1, Liver 2)

(A)

\begin{tabular}{|c|c|c|c|c|c|}
\hline CYP450 enzyme & $\begin{array}{l}\text { UniProt } \\
\text { accession } \\
\text { code }\end{array}$ & $\begin{array}{c}\text { No. of } \\
\text { observed } \\
\text { peptides }\end{array}$ & $\begin{array}{l}\text { No. of unique } \\
\text { peptides }\end{array}$ & $\begin{array}{c}\text { emPAI } \\
\text { (individual } \\
\text { values) }\end{array}$ & Examples of unique peptides \\
\hline CYP1A2 & F1SJ26 & 9 & 7 & $0.87(0.75,0.87)$ & $\begin{array}{l}\text { HSEENSSTSGGLISQEK, NCIQDITSALFK, } \\
\text { DTTLNGFYIPK, FLTADGTAIHK }\end{array}$ \\
\hline CYP2A19 & Q8SQ68 & 21 & 16 & $2.57(2.16,2.16)$ & $\begin{array}{l}\text { IVVLCGYDAVK, DFIDSFLIR, DLQGLEDFIAR, } \\
\text { GAFIDPTYFLSR }\end{array}$ \\
\hline CYP2C33v4 & Q8SQ66 & 16 & 12 & $2.05(2.05,2.05)$ & $\begin{array}{l}\text { HPEVQAK, PISVGLFNLPPPFK, } \\
\text { QYGPVCTVYFGSQPAVVLHGYEAVK }\end{array}$ \\
\hline CYP2C34 & Q5S8C4 & 10 & 2 & $1.42(1.22,1.42)$ & YGLLLMLK, EALIGGEEFSGR \\
\hline CYP2C42 & P79402 & 5 & 1 & $0.42(0.42,0.32)$ & GTTILTSLTSVLYDCK \\
\hline CYP2C49 & $\begin{array}{l}\text { Q8SQ65F1S } \\
\text { C62 }\end{array}$ & 18 & 7 & $2.16(2.16,1.78)$ & $\begin{array}{l}\text { EALIDGGEEFSGR, FTLEPVVDLK, } \\
\text { GHGIIFSSGK, YIDLIPISVPHAVTR }\end{array}$ \\
\hline CYP2D25 & O46658 & 23 & 21 & $4.23(4.23,4.23)$ & $\begin{array}{l}\text { DLAQPPR, PFSPNNLLNK, QVLEAMPVLR, } \\
\text { AFLVMIDELITEHK }\end{array}$ \\
\hline CYP2E1 & P79383 & 18 & 14 & $1.82(1.51,1.82)$ & $\begin{array}{l}\text { DFTDTLLMEMEK, FIDLIPSNLPHEATR, } \\
\text { GTVVIPTLDSVLYDSQEFPEPEK }\end{array}$ \\
\hline CYP2S1 & M3VK37 & 1 & 1 & $0.10(0.10,0.10)$ & RVCLGEGLAR \\
\hline CYP3A22 & $\begin{array}{l}\text { A0A0H4I } \\
\text { V24 }\end{array}$ & 10 & 2 & $1.05(0.81,0.95)$ & DPFYQYAR, DSINPYTYLPFGTGPR \\
\hline CYP3A29 & P79401 & 6 & 1 & $0.56(0.56,0.45)$ & LTTQGLTQPEKPVVLK \\
\hline CYP3A46 & A7KZR2 & 12 & 2 & $1.59(0.89,1.04)$ & LQEEIDATFPNK, MWGFFDGR \\
\hline CYP4A21 & Q9GJX5 & 15 & 4 & $1.68(1.68,1.51)$ & $\begin{array}{l}\text { IPVPIQGIVLK, MENGNSLSDTDVR, } \\
\text { VVVALTLLR }\end{array}$ \\
\hline CYP4V2 & $\begin{array}{l}\text { A0A0B8R } \\
\text { TT2 }\end{array}$ & 6 & 3 & $0.48(0.39,0.48)$ & $\begin{array}{l}\text { KVDNELDEVFGK, DFFQQLIR, } \\
\text { NIGAQSNDDSEYVR }\end{array}$ \\
\hline CYP20A1 & $\begin{array}{l}\text { A0A0H4IR } \\
\text { A9 } \\
\end{array}$ & 7 & 6 & $0.68(0.45,0.56)$ & $\begin{array}{l}\text { IDTFIIPK, LYEEIDQVFGK, } \\
\text { SVTQMVMGSTFEDEQEVIR, TSDPFETMLK }\end{array}$ \\
\hline CYP51A1 & O46420 & 6 & 6 & $0.58(0.58,0.58)$ & $\begin{array}{l}\text { DLNLLDR, NEDLNAEDVYSR, } \\
\text { SPIEFLENAYEK }\end{array}$ \\
\hline \multicolumn{6}{|l|}{ (B) } \\
\hline UGT enzyme & $\begin{array}{c}\text { UniProt } \\
\text { accession } \\
\text { code } \\
\end{array}$ & $\begin{array}{c}\text { No. of } \\
\text { observed } \\
\text { peptides }\end{array}$ & $\begin{array}{l}\text { No. of unique } \\
\text { peptides }\end{array}$ & $\begin{array}{c}\text { emPAI } \\
\text { (individual } \\
\text { values) }\end{array}$ & Examples of unique peptides \\
\hline UGT1A1* & M1VEG8 & & 7 & $2.32(1.72,2.32)$ & $\begin{array}{l}\text { DSALLLSACSHLLHNK, } \\
\text { GHDTVVVAPDATMYIK, NDFVNNYPR, } \\
\text { PIMPNTVFIGGINCASK }\end{array}$ \\
\hline UGT1A3* & F1SM17 & 11 & 4 & $1.33(1.00,1.15)$ & $\begin{array}{l}\text { LLTMNSDHMTFFQR, } \\
\text { SYATPYTQDEFDDLMVR, VFLMFER }\end{array}$ \\
\hline UGT1A6 & $\begin{array}{c}\text { A0A0D6A } \\
5 \mathrm{~J} 1 \\
\end{array}$ & 16 & 6 & $1.96(1.76,1.76)$ & $\begin{array}{l}\text { DAATLSFLR, LLVVPQDGSHWLSMK, } \\
\text { TPSPTSYVPR, VANFLTR }\end{array}$ \\
\hline UGT2B17* & F1RUR0 & 16 & 7 & $2.41(2.16,1.93)$ & $\begin{array}{l}\text { DSLWTHLLK, GHEVTVLTSPAAVVVDVNK, } \\
\text { IQNFFWK }\end{array}$ \\
\hline UGT2B31* & F1RUQ8 & 16 & 10 & $2.73(2.16,2.73)$ & $\begin{array}{l}\text { ANTIASAFAQIPQK, ITTAQNIFSELSDVSLK, } \\
\text { QVINNPFYK, TDLVNALK }\end{array}$ \\
\hline \multicolumn{6}{|l|}{ (C) } \\
\hline Transporter & $\begin{array}{c}\text { UniProt } \\
\text { accession } \\
\text { code } \\
\end{array}$ & $\begin{array}{c}\text { No. of } \\
\text { observed } \\
\text { peptides }\end{array}$ & $\begin{array}{l}\text { No. of unique } \\
\text { peptides }\end{array}$ & $\begin{array}{c}\text { emPAI } \\
\text { (individual } \\
\text { values) } \\
\end{array}$ & Examples of unique peptides \\
\hline $\mathrm{ABCA} 8 *$ & I3LDW8 & 9 & 6 & $0.32(0.32,0.24)$ & $\begin{array}{l}\text { EMSVCQQTGALLCK, LSQTAYLENISK, } \\
\text { RSDVCPNPEEPEGEDEDVQMER }\end{array}$ \\
\hline $\mathrm{ABCB} 1$ & $\begin{array}{l}\text { A0A0E3M } \\
\text { Y68 } \\
\end{array}$ & 5 & 4 & $0.18(0.18,0.18)$ & LYDPTEGVVSIDGQDIR, IATEAIENFR \\
\hline $\mathrm{ABCB} 11$ & F1S1W3 & 15 & 12 & $0.58(0.58,0.58)$ & $\begin{array}{l}\text { AGSVADEVISSIR, GGGSQVGLFQLFR, } \\
\text { VNDAIADQMAIFIQR }\end{array}$ \\
\hline $\mathrm{ABCC} 1 *$ & F1RLT0 & 3 & 2 & $0.09(0.06,0.03)$ & LSSVLDCAR, ITIIPQDPILFPGSLR \\
\hline $\mathrm{ABCC} 2$ & F1S8V9 & 13 & 12 & $0.49(0.40,0.40)$ & $\begin{array}{l}\text { ATYQNSDIYILDDPLSAVDAHVGR, } \\
\text { GTVAYVPQQSWIQNGTIK } \\
\end{array}$ \\
\hline
\end{tabular}




\begin{tabular}{|c|c|c|c|c|c|}
\hline $\mathrm{ABCC} 3$ & F1RTA1 & 14 & 11 & $0.54(0.40,0.54)$ & $\begin{array}{l}\text { GALVAVVGPVGCGK, IDGLNVADIGLHDLR } \\
\text { SSLVSALLGEMEK }\end{array}$ \\
\hline $\mathrm{ABCF} 1$ & Q767L0 & 5 & 5 & $0.28(0.22,0.28)$ & $\begin{array}{l}\text { IGFFNQQYAEQLR, LQGQLEQGDDTAADR, } \\
\text { NQDEESQEAPELLK }\end{array}$ \\
\hline ABCE1 & K9J4N5 & 13 & 13 & $1.20(1.07,1.07)$ & $\begin{array}{l}\text { CPFGALSIVNLPSNLEK, } \\
\text { PADVYLIDEPSAYLDSEQR, } \\
\text { TQAIVCQQLDLTHLK }\end{array}$ \\
\hline ABCG2 & Q8MIB3 & 2 & 1 & $0.17^{+}$ & SSLLDVLAAR \\
\hline OATP1B4 & $\begin{array}{l}\text { A0A0E8P } \\
\text { PJ7 }\end{array}$ & 5 & 5 & $0.37(0.28,0.28)$ & $\begin{array}{l}\text { SSLTQIER, AVNEANLEPIR, LTLVGIAK, } \\
\text { TVNGFIQSLK }\end{array}$ \\
\hline OATP2B1 & $\begin{array}{c}\text { A0A0B8R } \\
\text { Z43 }\end{array}$ & 5 & 5 & $0.56(0.56,0.56)$ & $\begin{array}{l}\text { ATMSSPGLQQQLLVSGPK, } \\
\text { VEYLTPCHAGCTSR, GEDSPSEQSPGASPEK }\end{array}$ \\
\hline \multicolumn{6}{|c|}{ Membrane Marker } \\
\hline $\mathrm{ATP} 1 \mathrm{~A} 1^{\S}$ & AT1A1 & 33 & 33 & $3.71(3.09,2.56)$ & $\begin{array}{l}\text { GVGIISEGNETVEDIAAR, SPDFTNENPLETR, } \\
\text { VDNSSLTGESEPQTR, } \\
\text { QGAIVAVTGDGVNDSPALK }\end{array}$ \\
\hline $\mathrm{ATP} 1 \mathrm{~B} 1^{\S}$ & AT1B1 & 7 & 6 & $1.74(1.74,1.37)$ & $\begin{array}{l}\text { AYGENIGYSEK, DDMIFEDCGNVPSELK, } \\
\text { TEISFRPNDPQSYESYVVSIVR }\end{array}$ \\
\hline
\end{tabular}

* Porcine transporters were putatively identified using iterative Needleman-Wunsch pairwise alignment against corresponding mammalian transporter subfamily sequences

ॠ Detected only in one sample (Liver 1) using one method (FASP)

${ }^{\S} \mathrm{ATP} 1 \mathrm{~A} 1$ and $1 \mathrm{~B} 1$ are $\mathrm{Na}^{+} / \mathrm{K}^{+}$ion transporters and markers for the basolateral membrane of hepatocytes 
Table 3 Additional Phase I and Phase II drug metabolising enzymes and accessory proteins identified by LC- MS/MS and their relative quantification. Accessory electron-transfer proteins (CYB5 and POR) are necessary for the function of cytochrome P450 enzymes. emPAI is calculated based on integrated data from the analysis of two livers. The individual data represent values for each sample considered separately (Liver 1, Liver 2)

\begin{tabular}{|c|c|c|c|c|c|}
\hline Protein/Enzyme & $\begin{array}{c}\text { UniProt } \\
\text { Accession code }\end{array}$ & $\begin{array}{c}\text { No. of } \\
\text { observed } \\
\text { peptides } \\
\end{array}$ & $\begin{array}{c}\text { No. of } \\
\text { unique } \\
\text { peptides }\end{array}$ & $\begin{array}{c}\text { emPAI } \\
\text { (individual } \\
\text { values) } \\
\end{array}$ & Examples of unique peptides \\
\hline \multicolumn{6}{|l|}{ Phase I } \\
\hline \multicolumn{6}{|l|}{ Oxidation } \\
\hline \multicolumn{6}{|c|}{ Flavin-containing monooxygenases } \\
\hline FMO1 & P16549 & 21 & 19 & $4.30(3.52,3.18)$ & $\begin{array}{l}\text { HEDFNTTGQWDVVTLCEGK, } \\
\text { MNSWFNHANYGLIPEDR, } \\
\text { VAIVGAGVSGLASIK } \\
\end{array}$ \\
\hline FMO3 & I3LS94 & 12 & 10 & $1.37(1.05,0.91)$ & $\begin{array}{l}\text { NNLPTVISDWWYTK, SCLEEGLEPTCFER, } \\
\text { KEPVFNDELPACILR }\end{array}$ \\
\hline FMO5 & P49109 & 14 & 9 & $1.34(0.95,0.83)$ & $\begin{array}{l}\text { CCLEEGLEPICFER, EFTETAAIFEDGSR, } \\
\text { LAFQLLWGPCTPIQYR } \\
\end{array}$ \\
\hline \multicolumn{6}{|c|}{ Alcohol dehydrogenases } \\
\hline AK1A1 & P50578 & 6 & 4 & $0.74(0.74,0.74)$ & ALEALVAK, GLEVTAYYSPLGSSDR, SPAQILLR \\
\hline $\mathrm{ADH} 4$ & F1S0Y8 & 16 & 14 & $5.31(5.31,4.62)$ & $\begin{array}{l}\text { ALGATDCLNPR, FNLDALVSHTLPFDK, } \\
\text { VCLLGCAFSTGYGAVVNTAK }\end{array}$ \\
\hline \multicolumn{6}{|c|}{ Aldehyde dehydrogenases } \\
\hline ALDH1B1 & F1ST54 & 14 & 8 & $1.74(1.37,1.74)$ & $\begin{array}{l}\text { ILGYIQLGQK, LAPALATGNTVVMK, } \\
\text { VAEQTPLSALYLASLIK }\end{array}$ \\
\hline ALDH1L1 & I3LEN7 & 35 & 28 & $5.24(4.06,4.62)$ & $\begin{array}{l}\text { AGFTIFWADDGLDTGDLLLQK, } \\
\text { DAFEHGLWGR, LPQPEEGATYEGIQK }\end{array}$ \\
\hline ALDH5A1 & F1RUE3 & 16 & 14 & $2.16(2.16,1.94)$ & $\begin{array}{l}\text { AMEVGEALCTDPLVSK, EETFGPLAPVIK, } \\
\text { ISFTGSTATGK, TDGFVGGR }\end{array}$ \\
\hline ALDH6A1 & F1S3H1 & 22 & 18 & $3.64(3.04,2.27)$ & $\begin{array}{l}\text { AEMDAAVSSCK, AISFVGSNQAGEYIFER, } \\
\text { IVNDNPYGNGTAIFTTNGATAR }\end{array}$ \\
\hline ALDH8A1 & I3LQA1 & 11 & 8 & $3.44(2.87,3.44)$ & $\begin{array}{l}\text { NPAIIFEDANLEECVPTTVR, } \\
\text { LADLLEESLEELAQAESK, IAPAIAAGNTVIAK }\end{array}$ \\
\hline ALDH9A1 & F1S232 & 18 & 14 & $2.07(1.71,1.88)$ & $\begin{array}{l}\text { ANDTTFGLAAGVFTR, } \\
\text { GALMANFLTQGEVCCNGTR, FTEEVVK }\end{array}$ \\
\hline ALDH16A1 & F1RHZ9 & 9 & 7 & $1.00(0.85,1.00)$ & $\begin{array}{l}\text { ASLENWSTLPGAFR, AWDQEAEGAGPELGLR, } \\
\text { EALALANGTPGGGSASVWSER }\end{array}$ \\
\hline ALDH2 & Q2XQV4 & 21 & 19 & $4.62(4.18,4.18)$ & $\begin{array}{l}\text { TFPTVNPSTGDVICHVAEGDK, } \\
\text { VAFTGSTEVGHLIQVAAGK, RLDASDR }\end{array}$ \\
\hline \multicolumn{6}{|c|}{ Monoamine oxidases } \\
\hline MAOA & Q6Q2J0 & 5 & 3 & $0.43(0.43,0.43)$ & $\begin{array}{l}\text { NENVDYVDVGGAYVGPTQNR, } \\
\text { FVGGSGQVSER, VNVNECLVQYVK }\end{array}$ \\
\hline MAOB & Q6PLK3 & 14 & 12 & $1.45(1.30,1.30)$ & $\begin{array}{l}\text { LERPVVHIDQTGENVLVETLNHEVYEAK, } \\
\text { LCDLYAK }\end{array}$ \\
\hline AOC3 & F1S1G8 & 9 & 8 & $0.66(0.66,0.57)$ & $\begin{array}{l}\text { VLETEEQAAFPVGGAAPR, LGPGLVDAAQAR, } \\
\text { EYLDIDQMIFR }\end{array}$ \\
\hline \multicolumn{6}{|l|}{ Hydrolysis } \\
\hline \multicolumn{6}{|l|}{ Esterases } \\
\hline EST1 & Q29550 & 21 & 10 & $5.42(5.42,5.42)$ & $\begin{array}{l}\text { AISESGVALTVALVR, DFNTVPYIVGINK, } \\
\text { ESHPFLPTVVDGVLLPK }\end{array}$ \\
\hline $\begin{array}{l}\text { Amidases } \\
\mathrm{N} \text {-acylethanolamin } \\
\text { hydrolysing acid } \\
\text { amidase (NAAA) }\end{array}$ & A0A0B8RZC6 & 1 & 1 & $0.14(0.14,0.14)$ & NLDYAFGR \\
\hline \multicolumn{6}{|l|}{ Epoxide hydrolases } \\
\hline EPHX1 & HYEP & 24 & 16 & $5.72(4.74,4.74)$ & $\begin{array}{l}\text { LGFQEFYLQGGDWGSLICTNMAQLVPSHVK, } \\
\text { FHYGFNSNYLK }\end{array}$ \\
\hline EPHX2 & HYES & 12 & 7 & $1.25(1.25,1.11)$ & $\begin{array}{l}\text { ELGGLFVGTPEEPSLSR, GFLNEAFK, } \\
\text { GFSTCILTNNWLDDSAQR }\end{array}$ \\
\hline
\end{tabular}

Phase II - Conjugation

Methylation

Methyltransferases

\begin{tabular}{llllll}
\hline AMT & I3LIR4 & 7 & 5 & $1.34(1.34,1.07)$ & CGYTGEDGVEISVPAAEAVR, \\
LATALLENPEVK, MVAFAGWSLPVQYR
\end{tabular}




\begin{tabular}{|c|c|c|c|c|c|}
\hline BHMT & E7D6R2 & 22 & 16 & $6.02(4.38,4.88)$ & $\begin{array}{l}\text { AHLMSQPLAYHTPDCGK, } \\
\text { IASGRPYNPSMSKPDAWGVTK }\end{array}$ \\
\hline ВНMT-2 & E7D6R3 & 14 & 5 & $4.01(2.16,3.47)$ & $\begin{array}{l}\text { GDALVAGGLCQTSLYK, } \\
\text { GGFVDLPEYPFALEPR, YIGGCCGFEPYHIR }\end{array}$ \\
\hline METTL7A & A0A0B8RSL6 & 4 & 2 & $0.93(0.93,0.93)$ & LSLLELGCGTGTNFK, ELFSNLQEFAGSSGK \\
\hline SHMT2 & F1SL74 & 12 & 11 & $1.20(1.06,1.20)$ & $\begin{array}{l}\text { GWSGQESLSDSDPEMWELLR, } \\
\text { ISATSIFFESMPYK, LGTPALTSR }\end{array}$ \\
\hline \multicolumn{6}{|l|}{ Sulfation } \\
\hline SULT1C4 & I3LC84 & 10 & 7 & $1.85(1.31,1.31)$ & $\begin{array}{l}\text { IPFLESGLEQAEAMPSPR, VCWGSWYDHVR, } \\
\text { FDEDYGK }\end{array}$ \\
\hline SULT2A1 & Q3S3F7 & 11 & 11 & $2.01(2.01,1.72)$ & $\begin{array}{l}\text { KLEPEELSSVVENSSFQVMK, FEGIFFPK, } \\
\text { EEDVLILTFPK }\end{array}$ \\
\hline \multicolumn{5}{|c|}{ Glutathione conjugation } & Glutathione S-transferases \\
\hline GSTK1 & F1SRV4 & 11 & 8 & $2.79(1.98,2.36)$ & $\begin{array}{l}\text { AGMSTGQAR, DEDITEPQSVLAAAEK, } \\
\text { YGAFGLPITVAHLDDK }\end{array}$ \\
\hline GSTA1 & F1S7D3 & 10 & 10 & $3.64(3.64,3.64)$ & $\begin{array}{l}\text { LTNDGSLLFQQVPMVEIDGMK, LEEAKNIFRIK, } \\
\text { VSNLPTVK }\end{array}$ \\
\hline GSTA2 & A0A0K1TR52 & 10 & 10 & $3.22(3.22,2.65)$ & $\begin{array}{l}\text { NDGSLLFQQVPMVEIDGMK, PILHYFNGR, } \\
\text { WLLAAAGVEFEEK }\end{array}$ \\
\hline GSTO1 & Q9N1F5 & 9 & 4 & $2.16(1.45,1.78)$ & $\begin{array}{l}\text { AFNDLYLQNSPEACDYGL, DPAVSALHIEPR, } \\
\text { TLLVLNAK }\end{array}$ \\
\hline MGST1 & P79382 & 4 & 3 & $2.16(2.16,2.16)$ & $\begin{array}{l}\text { IYHTIAYLTPLPQPNR, KVFANPEDCSSFGK, } \\
\text { MMFMSTATAFYR }\end{array}$ \\
\hline MGST2 & A0A0K1TQQ0 & 2 & 2 & $1.51(0.58,1.51)$ & VMPPAVSGSPEFER, YFWGYSEAPK \\
\hline MGST3 & Q2EN77 & 2 & 1 & $0.78(0.78,0.78)$ & VLYAYGYYTGEPSK \\
\hline \multicolumn{6}{|c|}{ CYP450 auxiliary proteins } \\
\hline CYB5 & CYB5 & 5 & 5 & $0.69(0.69,0.69)$ & STWLILHHK, FLEEHPGGEEVLR \\
\hline $\begin{array}{l}\text { NADPH CYP450 } \\
\text { reductase }\end{array}$ & NCPR & 15 & 10 & $1.54(1.39,1.54)$ & $\begin{array}{l}\text { EELAQFHAK, EVGETLLYYGCR, } \\
\text { NPFLAVVTTNR }\end{array}$ \\
\hline
\end{tabular}


Table 4 The identified porcine cytochrome P450 enzymes (A), UGT enzymes (B) and transporters (C), and their human homologues with the highest primary sequence identity and similarity. Relative abundance of porcine drug-metabolising enzymes and drug transporters and their human homologues are listed. Where individual human homologues could not be decided due to extensive homology, the relative abundance of the enzyme subfamily in pig and human was compared

(A)

\begin{tabular}{|c|c|c|c|c|c|}
\hline $\begin{array}{l}\text { Porcine } \\
\text { CYP450 }\end{array}$ & $\begin{array}{l}\text { Equivalent human } \\
\text { CYP450 }\end{array}$ & Identity & Similarity & $\begin{array}{l}\text { Relative } \\
\text { abundance in } \\
\text { pig* }\end{array}$ & $\begin{array}{l}\text { Relative } \\
\text { abundance of } \\
\text { human } \\
\text { homologue* }\end{array}$ \\
\hline CYP1A2 & CYP1A2 & $81 \%$ & $91 \%$ & $5 \%$ & $10 \%$ \\
\hline \multirow[t]{2}{*}{ CYP2A19 } & CYP2A13 & $90 \%$ & $95 \%$ & \multirow{2}{*}{$14 \%$} & \multirow{2}{*}{$7 \%$} \\
\hline & CYP2A6 & $87 \%$ & $94 \%$ & & \\
\hline CYP2C33 & CYP2C9 & $63 \%$ & $80 \%$ & & \\
\hline CYP2C34 & CYP2C18 & $78 \%$ & $90 \%$ & & \\
\hline CYP2C42 & CYP2C18 & $82 \%$ & $92 \%$ & $32 \%$ (CYP2C) & $25 \%(C$ \\
\hline \multirow[t]{2}{*}{ CYP2C49 } & CYP2C18 & $81 \%$ & $90 \%$ & & \\
\hline & CYP2C8 & $76 \%$ & $86 \%$ & & \\
\hline CYP2D25 & CYP2D6 & $78 \%$ & $87 \%$ & $22 \%$ & \\
\hline CYP2E1 & CYP2E1 & $79 \%$ & $91 \%$ & $10 \%$ & \\
\hline CYP2S1 & CYP2S1 & $78 \%$ & $87 \%$ & - & \\
\hline \multirow[t]{2}{*}{ CYP3A22 } & CYP3A4 & $76 \%$ & $87 \%$ & & \\
\hline & CYP3A5 & $72 \%$ & $87 \%$ & & \\
\hline \multirow[t]{2}{*}{ CYP3A29 } & CYP3A4 & $77 \%$ & $87 \%$ & & $20 \%$ \\
\hline & CYP3A5 & $76 \%$ & $88 \%$ & & 5270 (C) \\
\hline \multirow[t]{2}{*}{ CYP3A46 } & CYP3A4 & $77 \%$ & (200 & & \\
\hline & CYP3A5 & $75 \%$ & & & \\
\hline CYP4A21 & CYP4A11 & $73 \%$ & $83 \%$ & - & - \\
\hline CYP4V2 & CYP4V2 & $79 \%$ & $90 \%$ & - & - \\
\hline CYP20A1 & CYP20A1 & 0207 & $97 \%$ & - & - \\
\hline CYP51A1 & CYP51A1 & & $98 \%$ & - & - \\
\hline \multicolumn{6}{|l|}{ (B) } \\
\hline $\begin{array}{l}\text { Porcine } \\
\text { UGT }\end{array}$ & $\begin{array}{l}\text { Equivalent } 1 \\
\text { UGT }\end{array}$ & Identity & Similarity & $\begin{array}{l}\text { Relative } \\
\text { abundance in } \\
\text { pig }\end{array}$ & $\begin{array}{l}\text { Relative } \\
\text { abundance of } \\
\text { human } \\
\text { homologue }\end{array}$ \\
\hline UGT1A1 & $\overline{\text { UGT1A1 }}$ & $81 \%$ & $90 \%$ & $22 \%$ & $10 \%$ \\
\hline UGT1A6 & UGT1A6 & $80 \%$ & $87 \%$ & $18 \%$ & $9 \%$ \\
\hline UGT1A3 & UGT1A3 & $80 \%$ & $87 \%$ & $12 \%$ & $7 \%$ \\
\hline \multirow[t]{3}{*}{ UGT2B17 } & UGT2B4 & $72 \%$ & $84 \%$ & & \\
\hline & UGT2B17 & $71 \%$ & $87 \%$ & & \\
\hline & UGT2B15 & $70 \%$ & $86 \%$ & 48\% (UGT2B) & $54 \%$ (UGT2B) \\
\hline \multirow[t]{2}{*}{ UGT2B31 } & UGT2B4 & $71 \%$ & $83 \%$ & & \\
\hline & UGT2B17 & $71 \%$ & $84 \%$ & & \\
\hline \multicolumn{6}{|l|}{ (C) } \\
\hline $\begin{array}{l}\text { Porcine } \\
\text { Transporter }\end{array}$ & $\begin{array}{l}\text { Equivalent human } \\
\text { Transporter }\end{array}$ & Identity & Similarity & $\begin{array}{l}\text { Relative } \\
\text { abundance in } \\
\text { pig }\end{array}$ & $\begin{array}{l}\text { Relative } \\
\text { abundance of } \\
\text { human } \\
\text { homologue }^{\#}\end{array}$ \\
\hline
\end{tabular}




\begin{tabular}{|c|c|c|c|c|c|}
\hline ATP $1 \mathrm{~A} 1^{\S}$ & ATP1A1 & $99 \%$ & $99 \%$ & - & - \\
\hline ATP1B $1^{\S}$ & ATP1B1 & $92 \%$ & $97 \%$ & - & - \\
\hline ABCA8 & ABCA8 & $75 \%$ & $82 \%$ & $8 \%$ & $7 \%$ \\
\hline $\mathrm{ABCB} 1$ & $\mathrm{ABCB} 1$ & $83 \%$ & $89 \%$ & $5 \%$ & $3 \%$ \\
\hline $\mathrm{ABCB} 11$ & $\mathrm{ABCB} 11$ & $88 \%$ & $93 \%$ & $15 \%$ & $11 \%$ \\
\hline $\mathrm{ABCC} 1$ & $\mathrm{ABCC} 1$ & $75 \%$ & $84 \%$ & & \\
\hline $\mathrm{ABCC} 2$ & $\mathrm{ABCC} 2$ & $82 \%$ & $90 \%$ & $29 \%$ (MRPs) & $35 \%$ (MRPs) \\
\hline $\mathrm{ABCC} 3$ & $\mathrm{ABCC} 3$ & $84 \%$ & $91 \%$ & & \\
\hline $\mathrm{ABCF} 1$ & $\mathrm{ABCF} 1$ & $97 \%$ & $98 \%$ & $7 \%$ & - \\
\hline ABCE1 & ABCE1 & $99 \%$ & $99 \%$ & $31 \%$ & - \\
\hline ABCG2 & ABCG2 & $84 \%$ & $90 \%$ & $5 \%$ & \\
\hline OATP1B4 & SLCO1B3 & $72 \%$ & $84 \%$ & $39 \%$ & \\
\hline ОАТР2B1 & SLCO2B1 & $80 \%$ & $88 \%$ & $00 \%$ & \\
\hline
\end{tabular}

*Relative abundance to total hepatic drug-metabolising CYP450 content; human data were collected from Achour et al. (2014a); abundance of subfamilies is used when individual homologues could not be decided (CYP2C, CYP3A)

tRelative abundance to total hepatic drug-metabolising UGT content; human data were taken from Achour et al. (2014b); abundance of subfamilies is used when individual homologues could not be decided (UGT2B)

\# Relative abundance to total hepatic ABC drug transporters content (for ABC transporters) or total hepatic OATP drug transporters content (for OATP transporters); human data were taken from Burt et al. (2016); abundance data for ABCC subfamily of transporters (multi-drug resistance proteins, MRPs) were combined

${ }^{\S} \mathrm{ATP} 1 \mathrm{~A} 1$ and $1 \mathrm{~B} 1$ are $\mathrm{Na}+/ \mathrm{K}+$ ion transporters and markers for the basolateral membrane of hepatocytes 


\section{Figure legends}
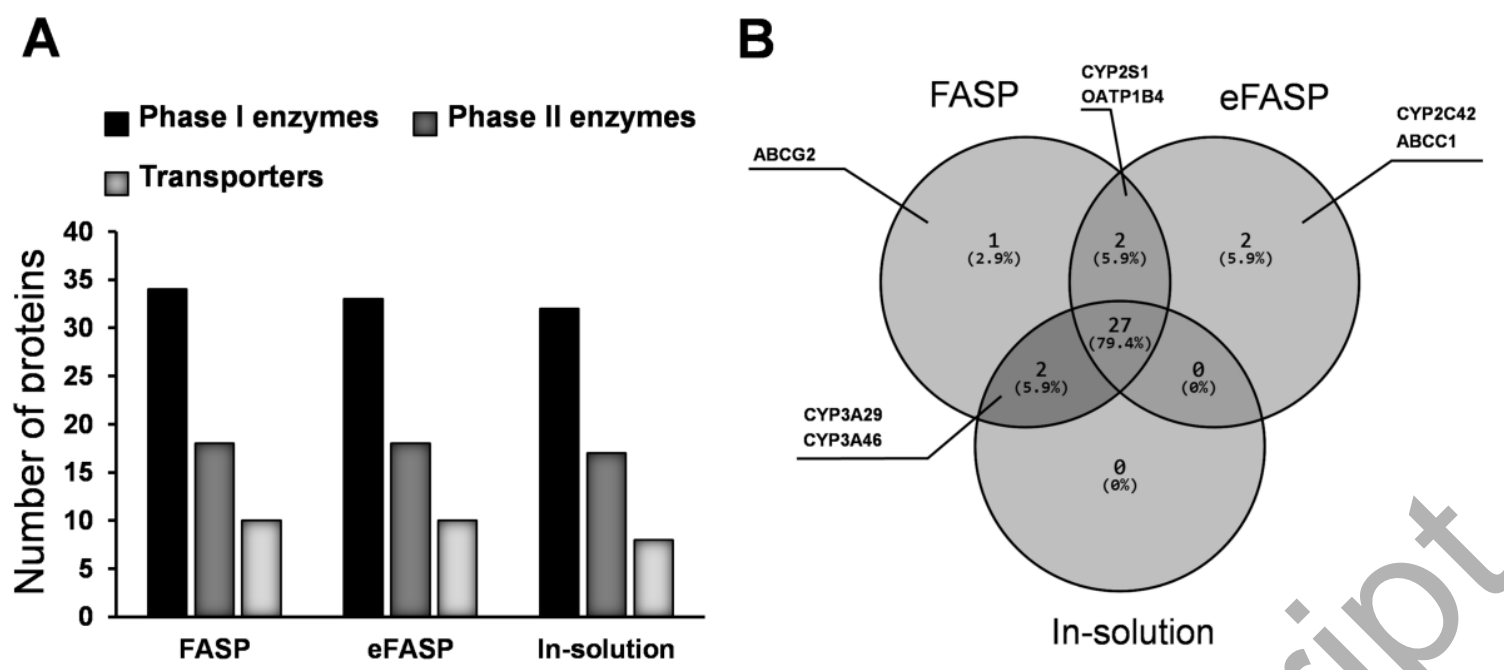

Figure 1 The total number of Phase I enzymes, Phase II enzymes and drug transporters identified by each sample preparation method based on unique peptides (A), and Venn diagram showing the overlap between cytochrome P450, UGT and transporter proteins that could be isolated by specific sample preparation protocols (B). FASP, filter-aided sample preparation; eFASP, enhanced FASP; in-solution, solution-based sample preparation 
A

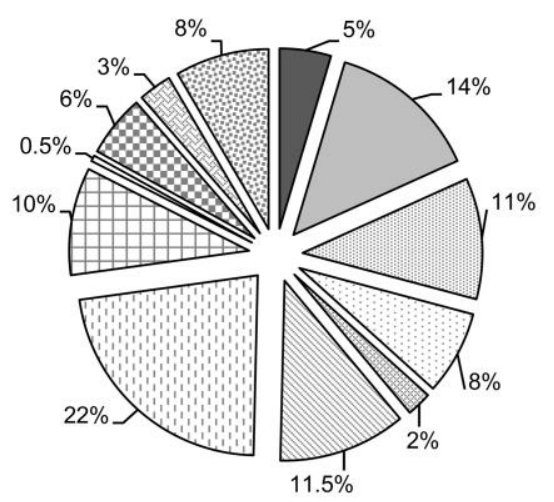

$\square$ CYP1A2

$\square$ CYP2A19

CYP2C33

CYP2C34

CYP2C42

$\square$ CYP2C49

口 CYP2D25

CYP2E1

CYP2S1

口 7 CYP3A22

$\square$ CYP3A29

图 CYP3A46

B

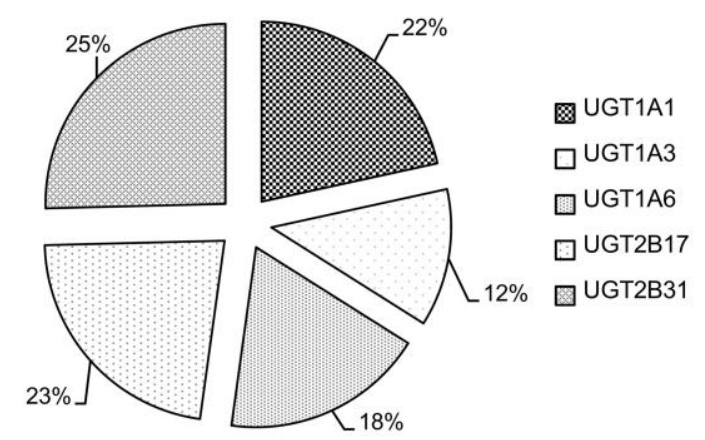

C

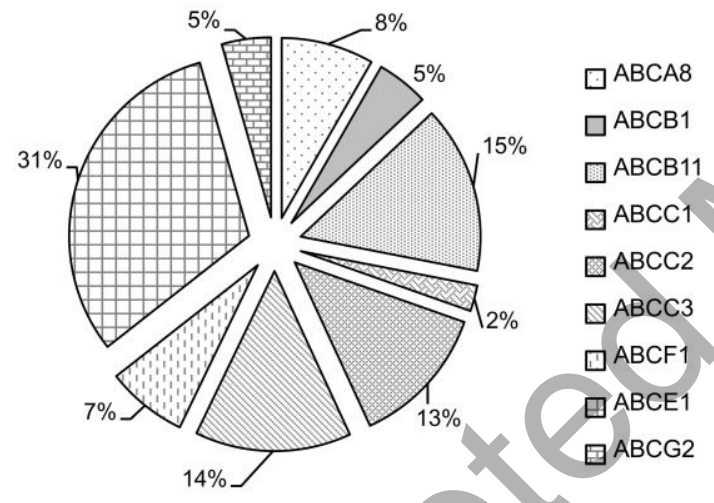

Figure 2 CYP450 (A), UGT (B), and ABC transporters (C) pig liver pie charts based on data from LC-MS/MS analysis and label-free quantification. The relative abundance values were calculated using spectral counting. The UGT pie represents the UGTs that could be identified in the experiments 


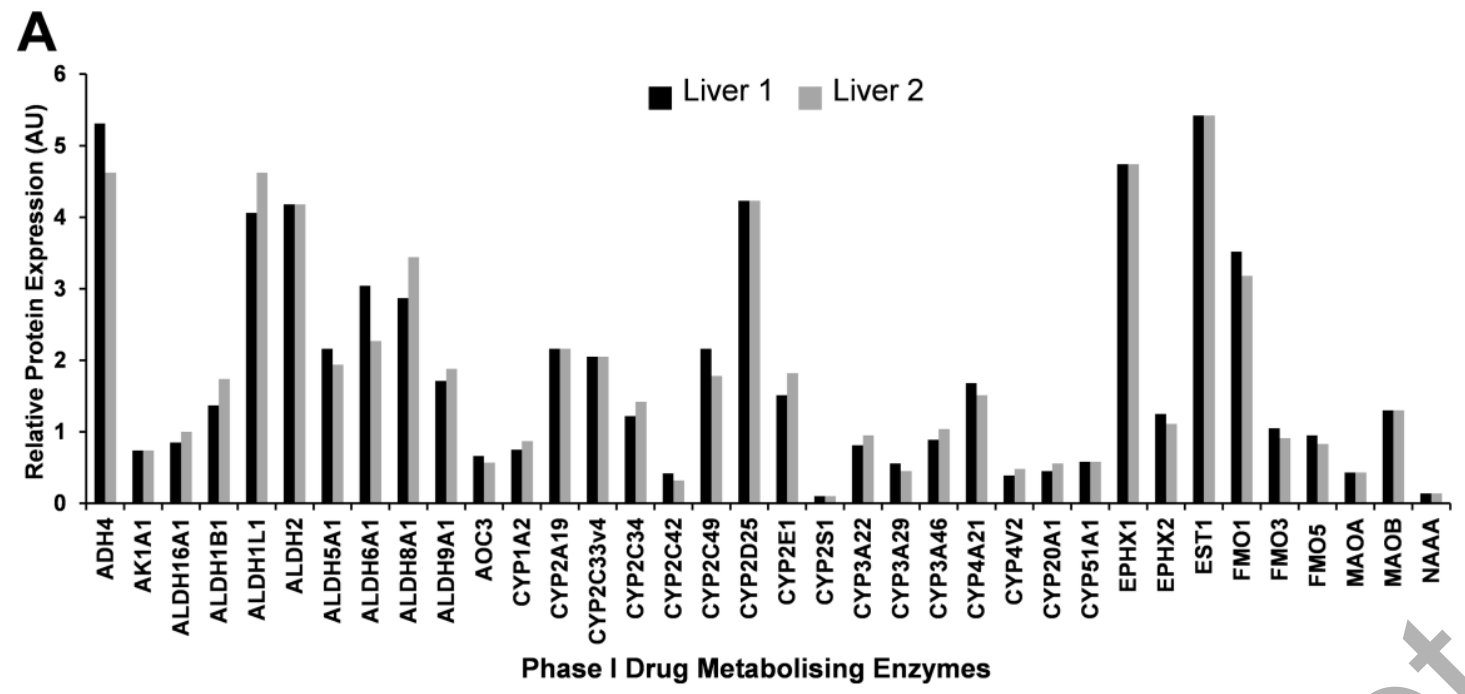

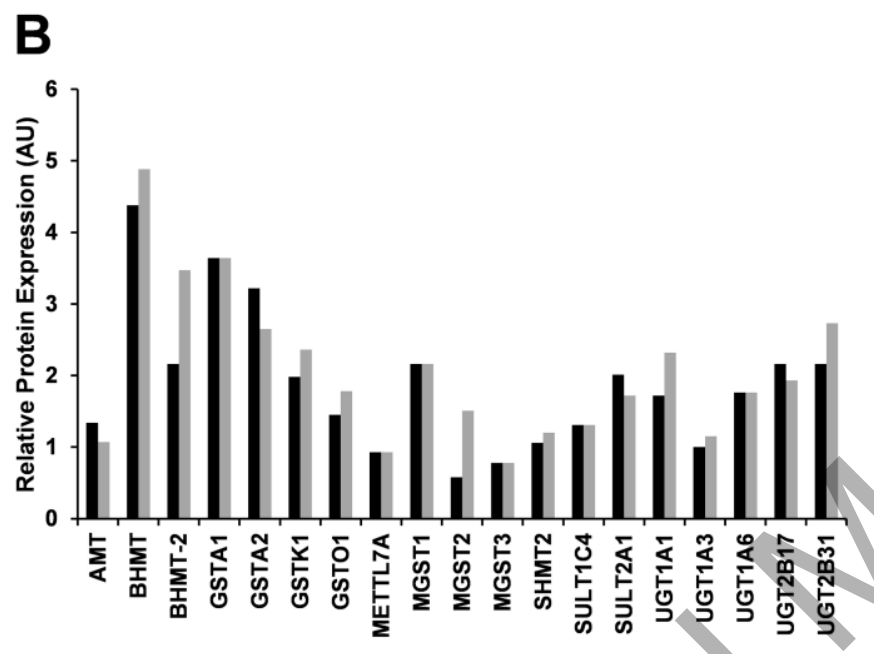

Phase II Drug Metabolising Enzymes

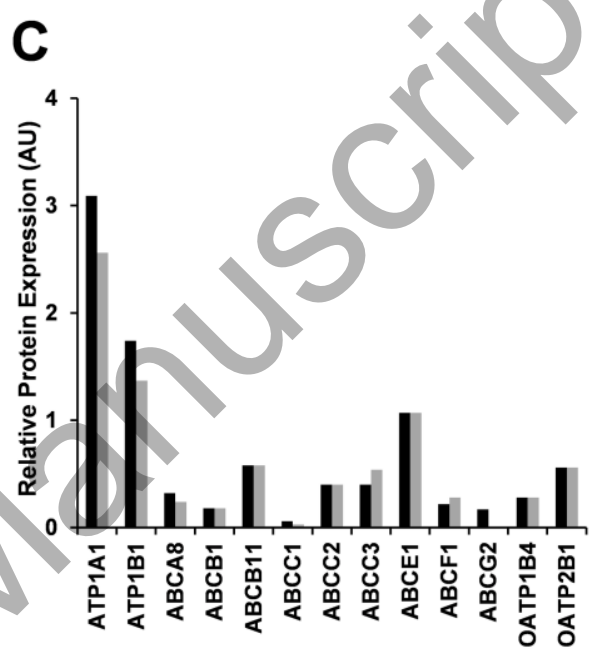

Transporter Proteins

Figure 3 Relative abundances of porcine Phase I (A) and Phase II (B) drug-metabolising enzymes and transporter proteins (C) in two pig livers using LC-MS spectral counting methodology. Results represent the combined quantification for each liver using the three different sample preparation methods. AU, arbitrary units based on the number of identified peptides using data-dependent acquisition (DDA) 